\title{
REKONSTRUKSI DEFINISI SUNNAH SEBAGAI PIJAKAN KONTEKSTUALITAS PEMAHAMAN HADITS
}

\author{
Nasrulloh \\ Fakultas Syariah UIN Maulana Malik Ibrahim Malang \\ Email: nasrulloh.said@gmail.com
}

\begin{abstract}
Canonization of sunnah into hadith massively appears to deal with extremism and arbitrary interpretations that have been critical to the sunnah of the Prophet. It marks the end of the interpretation process of the sunnah, including 'the living sunnah' because it was freely appreciated and interpreted by others and subsequently was turned into a verbal form. At this stage comes the new movement pioneered by Imam Shafi'i who spread the dogma that the required one is the sunnah of the Prophet. The sunnah that has validity as a source of Islamic law is the provable one through verbal transmission mechanism (hadith). The historical point of view shows difference, intersection and similarity between the hadith and sunnah. Tracing both the meaning of hadith and sunnah in depth will change the mindset of understanding the hadith and sunnah.
\end{abstract}

Kanonisasi sunnah ke dalam bentuk hadits muncul dalam skala besar untuk menghadapi ekstrimisme dan penafsiran sewenang-wenang yang sudah gawat terhadap sunnah Nabi. Ini menandai berakhirnya proses penafsiran terhadap sunnah Nabi, termasuk 'sunnah yang hidup' karena sunnah Nabi yang semula bebas dipahami dan ditafsirkan oleh generasi sahabat dan setelahnya sudah berubah bentuk menjadi verbal. Pada tahap ini muncullah gerakan baru yang dipelopori oleh Imam Syafi'i yang menyebarkan dogma bahwa sunnah yang harus dipegang adalah sunnah yang berasal dari Nabi. Sunnah yang memiliki keabsahan sebagai sumber hukum islam adalah sunnah yang dapat dibuktikan berasal dari Nabi melalui mekanisme transmisi verbal (hadits). Dengan pendekatan sejarah, diketahui adanya perbedaan dan persinggungan serta kesamaan antara hadits dan sunnah. Dengan menelusuri kedua makna 
hadits dan sunnah secara mendalam akan merubah pola pikir pemahaman terhadap hadits dan sunnah.

Keywords: Sunnah, Hadith, interpretation

\section{Pendahuuan}

Pada masa kontemporer sekarang ini, diperlukan pembacaan yang 'hidup' yang relevan dengan segala kompleksitas problem yang ada. Permasalahan-permasalahan yang ada sekarang ini tentunya berbeda dengan permasalahan pada masa dulu. Oleh karena itu problem-problem baru sekarang tentunya membutuhkan metode dan konsep yang baru juga, yang tidak dapat diselesaikan dengan sebagian seperangkat metode klasik. Adanya perkembangan dan perubahan situasi sosial, budaya, ilmu pengetahuan dan peradaban meniscayakan adanya epistemology baru yang sejalan dan searah dengan perubahan tersebut. Hal ini, diperkuat oleh pernyataan Amin Abdullah yang mengatakan bahwa perubahan situasi social politik, budaya, ilmu pengetahuan dan revolusi informasi turut memberi andil dalam usaha memaknai kembali teks-teks keagamaan (Abdullah, 2000: 93).

Terjadinya peralihan perubahan dari hadits yang bersifat a living tradition menjadi a literary tradition tidak terlepas dari kondisi-situasi yang mengitarinya. Pada masa itu (abad ke-2 dan ke-3 hijriyah) keberadaan sahabat, tabi' in dan tabi' al tabi' in yang mengerti secara persis bagaimana cara hidup dan perilaku Nabi amatlah langka, serta banyaknya hadits palsu yang muncul, mendorong generasi-generasi intelektual pada masa itu untuk membuat teori, konsep dan metode guna menyeleksi hadits-hadits yang dapat dipastikan dari Nabi dan yang bukan dari Nabi. Dengan kata lain, semua teori-teori dalam ilmu hadits merupakan hasil kreatifitas cendekiawan yang mungkin sesuai dan dapat diterapkan pada masa tersebut, dan tidak relevan lagi untuk diterapkan pada masa sekarang. Jadi, menurut pendekatan epistemology, ada proses yang bersifat historis dan panjang dalam pembukuan dan peletakan teoriteori pemahaman hadits Nabi. Proses ini yang sering kali diabaikan oleh sebagian umat islam (Abdullah, 2012: 140). Kenyataan ini dibuktikan dengan pernyataan sebagian tokoh intelektual muslim yang melarang adanya kritik terhadap hadits-hadits yang sudah dibukukan pada masa kodifikasi (Abbas, 2004: 38-39).

Fazlurrahman mengemukakan sebuah teori perkembangan hadits. Dalam perkembangannya, hadits mengalami tiga fase, informal, semiformal dan formal. Sunnah pada fase informal terjadi pada masa Nabi masih hidup, 
pembicaraan perihal Nabi hanyalah bagian dari peristiwa yang terjadi dalam kehidupan sehari-hari para sahabat. Proses periwayatan (transmisi verbal) tentang Nabi bukanlah suatu kesengajaan untuk sebuah orientasi praktis. Karena salah satu peranan hadits yang memberikan bimbingan dalam praktek aktual masyarakat waktu itu sudah terpenuhi oleh Nabi melalui perkataan, perbuatan, pernyataan, sikap dan teladan (Rahman, 1965: 69).

Fase semiformal terjadi setalah Nabi wafat, tepatnya pada masa sahabat dan tabi'in senior. Pada fase ini, penyebaran hadits Nabi mempunyai tujuan praktis, yakni sesuatu yang dapat dikembangkan menjadi praktek masyarakat muslim, peyebaran hadits menjadi sebuah kesengajaan. Pada masa ini, penafsiran bebas terhadap hadits Nabi oleh para penguasa dan hakim sesuai dengan situasi dan kondisi yang mereka hadapi pun menjadi sebuah keniscayaan, sehingga muncullah apa yang disebut dengan 'living sunnah' (sunnah yang hidup). Dampak dari perkembangan hadits secara semiformal adalah munculnya perbedaan praktek yang aktual di berbagai daerah dalam imperium islam, bahkan terkadang saling bertentangan.

Fase semiformal dalam perkembangan hadits, menyebabkan munculnya fase ketiga, yaitu fase formal. Fase ini menuntut adanya keseragaman dan standarisasi di seluruh Dunia Islam. Fase ini menyebabkan sunnah yang hidup yang bersifat dinamis dengan proses interpreasi yang terus menerus terhadapnya menjadi corpus tertutup, baku-kaku dan stagnan serta dianggap sebagai keputusan dan ketentuan yang bersifat final demi sebuah alasan untuk keseragaman dan penyatuan umat. Gerakan ini, dipelopori oleh al Syafi'i yang mempunyai tujuan menjaga stabilitas hukum dan menumbangkan haditshadits palsu yang pada waktu itu merajalela. Namun sayang, pada fase ini, sunnah yang semula bersifat dinamis berubah menjadi baku-kaku (Rahman, 1965: 32-33). Melalui kajian ini diharapkan pemahaman terhadap hadits Nabi yang kaku, baku dan tekstual kembali semula menjadi sunnah yang luwes, lentur, dan kontekstual, dengan begitu baik hadits maupun sunnah akan selalu eksis dan shalih li kulli zaman wa makan.

\section{Hadits dan Sunnah dalam Perspektif Pemikir Klasik-Kontemporer} a. Definisi Hadits.

Secara etimologi, hadits berasal dari derivasi kata hadatsa yang mempunyai makna kaun al shai' ba'da an lam yakun yang berarti adanya sesuatu setelah tidak adanya (al Asfahani, tt: 450), hadits juga berarti jadid (baru), bisa juga bermakna khabar (berita) (al Mandhur, tt, p: 438), dan bisa juga berarti kalam (Salih, 1989: 3). 
Kata 'hadits' disebutkan dalam al Quran sebanyak 28 kali dengan rincian 23 kali dalam bentuk mufrad dan 5 kali dalam bentuk jama'(Baqi, 1992: 247-248). Kata 'hadits' dalam al Quran maupun kitab-kitab hadits secara literal mempunyai beberapa arti: (a) komunikasi religius, pesan atau al Quran. Sebagaimana yang tercantum dalam surat al Zumar ayat 23. (b) cerita duniawi atau kejadian alam yang wajar, sebagaimana yang tercantum dalam surat al An'am ayat 68. (c) cerita sejarah, sebagaimana yang tercantum dalam surat Taha ayat 9. (d) rahasia, percakapan atau cerita yang masih hangat, sebagaimana yang tercantum dalam surat al Tahrim ayat 3 (Azami, 1977: 1-2). Dari keempat makna yang telah dikemukakan tadi, semuanya terangkum dalam pengertian cerita dan percakapan. Ignaz Goldziher mengatakan bahwa hadits secara literal mempunyai makna lebih dari satu, yaitu tale (kisah atau cerita), communication (berita atau kabar), historical information (informasi sejarah), baik bersifat sekuler (duniawi) maupun religious (keagamaan), baik berhubungan dengan peristiwa yang sudah lampau maupun yang baru saja terjadi (Goldziher, 1971).

Secara terminology, hadits mempunyai makna segala sesuatu yang disandarkan kepada Nabi, baik berupa perkataan, perbuatan, ketetapan serta sifat-sifat fisik dan suri tauladan Nabi (Sabbaq, 1972: 14-17). Dalam pengertian yang semacam ini, hadits disinonimkan dengan istilah sunnah. Berdasarkan definisi tersebut, bentuk-bentuk hadits dapat dibedakan menjadi (a) sabda, (b) perbuatan, (c) taqrir, (d) hal ihwal Nabi, yaitu segala sifat dan keadaan beliau (al Siba'i, 1994: 53). Menurut Nuruddin 'Itr, definisi tersebut masih dirasa kurang sempurna, karena dalam kitab-kitab hadits banyak dijumpai perkataan-perkataan yang tidak bersumber dari Nabi, melainkan dari sahabat dan tabi'in. Sehingga pengertian hadits secara terminology, yang ideal adalah segala sesuatu yang disandarkan pada Nabi, berupa ucapan, perbuatan, taqrir, sifat-sifat fisik atau etik, dan juga segala sesuatu yang yang disandarkan kepada para sahabat dan tabi'in ('Itr, 1992: 9).

Hadits sering juga disinonimkan dengan khabar dan atsar. Al Shahrawy mengatakan bahwa sebagian ulama masih menganggap hadits sama dengan khabar sebagai apa saja yang disandarkan kepada Nabi atau selain Nabi (al Shahrawy, 1971: 10). Karena keduanya mempunyai makna yang sama secara bahasa. Selain itu, yang namanya periwayat, tidak terbatas meriwayatkan berita dari Nabi semata, tetapi periwayat juga mengambil berita dari sahabat dan tabi' in (Salih, 1989: 10). Sementara itu, ada sebagian kelompok ulama yang menyatakan bahwa khabar adalah sesuatu yang disandarkan kepada 
selain Nabi. Dari sini, dapat dibedakan antara orang yang menekuni hadits dan khabar. Orang yang mendalami bidang hadits disebut sebagai muhaddith, sedangkan yang menekuni bidang sejarah atau sejenisnya disebut akhbari (Khatib, 1989: 28).

Selain hal tersebut, mereka juga menyatakan bahwa hadits bersifat khusus, sedangkan khabar bersifat umum. Maka dari itu setiap haditsadalah khabar, dan tidak setiap khabar adalah hadits (Salih, 1989: 10), 'Ajaj al Khatib menjelaskan bahwa atsar merupakan sinonim khabar, yakni segala sesuatu yang disandarkan pada Nabi, sahabat dan tabi'in. Tetapi menurut Fuqaha Khurasan, khabar adalah sinonim hadits, sedangkan atsar hanya terbatas pada perkataan sahabat. Dalam ujaran lain, atsar digunakan untuk istilah hadits mauquf, sedangkan khabar untuk hadits marfu' (Khatib, 1989: 28).

\section{b. Definisi Sunnah.}

Sunnah secara bahasa mempunyai beragam arti, yaitu mengalir atau berlalunya sesuatu dengan mudah, jalan, tradisi, praktek yang diikuti, arah, model perilaku, ketentuan dan peraturan (al Fairuzzabadi, 1983: 237). Sunnah juga dapat diartikan sebagai jalan tengah, jalan lurus yang terpuji dan penengah diantara berbagai ekstrimisme. Ketika Abu Hanifah menulis surat kepada 'Uthman al Batti, yang di dalamnya berisi keterangan mengenai pendapatnya tentang seorang muslim yang melakukan dosa, sekaligus bantahan atas pandangan kaum Khawarij tentang orang yang berbuat dosa, Ia (Abu Hanifah) mengatakan bahwa pendapatnya ini sama dengan pendapatnya ahl al 'adl wa al sunnah atau orang-orang adil dan orang-orang yang berada di jalan tengah (Rahman, 1965: 3-4).

Kata sunnah dalam al Quran disebutkan sebanyak enam belas kali, baik dalam bentuk mufrad maupun jama' (Baqi, 1992: 466). Al Quran menggunakan istilah sunnah untuk beberapa konteks, yang secara garis besar berkenaan dengan dua hal. Pertama, ketetapan orang-orang terdahulu (sunnah al awwalin), yang dimaksud dalam konteks ini adalah kejadian-kejadian yang menimpa mereka akibat dari perbuatan yang telah mereka lakukan. Kedua, ketetapan Allah (sunnatullah) yang dimaksud disini adalah cara atau aturan Allah yang berlaku bagi semua hambanya (Ibrahim, tt: 254).

Ibnu Hajar mendefinisikan sunnah sebagai tata cara Nabi, sebagaimana hadits Nabi yang menyatakan bahwa siapa saja dari ummatnya yang tidak menyukai sunnahnya, maka ia bukanlah termasuk dari golongan Nabi (Hajar, 1992: 105). Definisi tersebut mendapat dukungan dari Mustafa Azami yang 
mengatakan bahwa dalam kitab-kitab hadits, kata sunnah disebutkan tidak kurang dari sepuluh redaksi hadits yang selalu berarti tata cara dan tingkah laku hidup yang menjadi anutan (Azami, 1994: 3).

Sementara itu, ulama ahli hadits mendefinisikan sunnah sebagai segala sesuatu yang berasal dari Nabi, berupa perkataan, perbuatan, ketetapan, karakteristik fisik dan etik, atau sejarah, baik sebelum kenabian seperti khalwat Nabi di Gua Hira', atau setelah kenabian (al Siba'i, 1994: 19). Sedangkan ulama ahli usul atau ushuliyyun, memberikan pengertian sunnah sebagai segala sesuatu yang disandarkan kepada Nabi selain al Quran, berupa perkataan, perbuatan, atau ketetapan yang menghasilkan dalil bagi hukum syariat. Di sisi lain, ulama ahli fiqh mengartikan sunnah sebagai segala sesuatu yang telah ditetapkan Nabi, yang tidak termasuk kategori fardhu atau wajib (Khatib, 1989: 19).

Terjadinya perbedaan pandangan ulama dalam memaknai sunnah, dipengaruhi oleh perbedaan sudut pandang mereka dalam memahami kedudukan Nabi Muhammad SAW. Ulama muhadditsun memandang Nabi sebagai sosok pemimpin dan pemberi teladan yang baik, sehingga wajar bila mereka mengambil apa saja yang berkaitan dengan Nabi. Sedangkan ulama ushuliyyunmemandang Nabi sebagai sosok legislator syariah yang menetapkan dasar-dasar hukum bagi mujtahid sesudah beliau dan yang menjelaskan kaidah-kaidah hidup untuk manusia. Sehingga wajar bila ulama ushuliyyun hanya memperhatikan sabda, perilaku dan persetujuan Nabi dalam konteks legislasi hukum dan pengukuhannya. Di sisi lain, fuqaha memandang Nabi sebagai pemberi petunjuk dalam hukum syara'. Sehingga mereka selalu melihat semua perbuatan manusia dari segi hukum wajib, sunnah, mubah, makruh dan haram (al Siba'i, 1994: 48-49).

\section{Keterkaitan Makna Hadits dan Sunnah}

Dalam pembahasan sebelumnya, sebagian ulama berpendapat bahwa antara hadits dan sunnah mempunyai makna yang sama. Tetapi penelusuran terhadap literatur-literatur klasik akan menghasilkan temuan bahwa antara hadits dan sunnah mempunyai makna dan penggunaan yang berbeda. Abd al Rahman al Mahdi mengatakan bahwa manusia itu bermacam-macam. Diantara mereka ada yang menjadi pakar dalam sunnah, tetapi tidak dalam hadits. Dan diantara mereka ada yang pakar di bidang hadits, tetapi tidak dalam sunnah (al Razi, tt: 118). Pernyataannya ini sudah jelas menunjukkan bahwa ada perbedaan makna dan penggunaan antara hadits dan sunnah. 
Literature lainnya yang menunjukkan adanya perbedaan istilah sunnah dan hadits adalah ungkapan al A'mashy. Dia mengatakan bahwa dirinya tidak mengetahui suatu kaum yang lebih utama dari suatu kaum yang mencari hadits ini dan mencintai sunnah ini. Abu Yusuf dalam salah satu statemenya mendesak agar mengikuti hadits yang memiliki kesesuaian dengan al Quran dan sunnah (Hasan, 1994: 87)

Ahmad ibnu Hanbal pernah mengatakan: "dalam hadits ini terdapat lima sunnah". Pernyataan tersebut disampaikan oleh Ahmad ibn Hanbal ketika mengomentari sabda Nabi tentang seorang muslim yang meninggal dunia dalam keadaan ihram. Demikian juga 'Aisyah ketika mengomentari hadits tentang Barirah, beliau mengatakan: "dalam masalah Barirah terdapat tiga sunnah (Hasan, 1994: 87). Subhi Saleh menulis bahwa ulama' hadits terkadang mengatakan: "hadits ini menyalahi qiyas, sunnah dan ijma”. Dalam kaitan ini, terdapat sebuah kitab yang berjudul al Sunnah bi Shawahid al Hadits, yang mengupas tentang sunnah yang di dukung oleh hadits. Dalam kitab tersebut ditunjukkan bahwa sunnah harus dibuktikan dengan haditshadits yang mendukungnya (Salih, 1989: 6) .

Beberapa kutipan pernyataan diatas menyebutkan bahwa ada perbedaan yang jelas antara hadits dan sunnah. Menurut Hasbi, hadits adalah segala sesuatu yang diceritakan oleh Nabi, sedangkan sunnah adalah sesuatu yang telah biasa dilakukan oleh kaum muslimin sejak dahulu, baik diceritakan ataupun tidak (al Siddiqie, 1991: 36). Pernyataan tersebut sejalan dengan pendapat Mahmudunnasir yang menjelaskan bahwa sunnah merupakan praktek-praktek dan kebiasan-kebiasaan umat terdahulu yang telah mapan dan disepakati bersama untuk dilestarikan dari satu generasi ke generasi berikutnya. Sedangkan hadits adalah hukum-hukum yang tetap dan pasti yang diucapkan oleh Nabi (Mahmudunnaser, 1981: 109).

Menurut Syuhudi Ismail, bila ditinjau dari segi kualitas amaliyah dan periwayatannya, maka hadits berada di bawah sunnah, sebab hadits merupakan suatu berita tentang sebuah peristiwa yang disandarkan pada Nabi, meski hanya sekali saja Nabi melakukannya dan hanya satu orang saja yang meriwayatkannya. Adapun sunnah merupakan amaliyah yang terus menerus dilaksanakan Nabi beserta sahabatnya, setelah itu dilakukan dan dilestarikan secara terus menerus oleh generasi berikutnya. Sebagai konsekwensinya, sunnah mempunyai satu tingkat lebih tinggi daripada hadits dari segi kekuatan hukumnya. Tetapi, meskipun berbeda, keduanya sama-sama bersumber dari Nabi. Dengan dasar inilah mayoritas ahli hadits menganggap tidak ada 
perbedaan antara hadits dan sunnah (Ismail, 1994: 5-6).

Fazlur Rahman mendefinisikan hadits sebagai tradisi verbal, sedangkan sunnah sebagai tradisi praktikal (Rahman, 1965: 68). Dengan kata lain, hadits merupakan bentuk verbal dari sebuah tradisi praktikal Nabi, sahabat dan juga tabi'in. Dari sini dapat diketahui bahwa munculnya hadits setelah adanya sunnah. Tidak jauh berbeda dengan Fazlurrahman, Goldziher mengartikan hadits sebagai laporan yang bersifat teoritis (verbal), sedangkan sunnah merupakan laporan yang telah memperoleh kualitas normativ serta menjadi prinsip praktis (practical rules). Satu-satunya karakteristik yang sama antar keduanya adalah kedua pengetahuan tersebut berakar pada tradisi (Goldziher, 1971: 24).

\section{Perkembangan dan Evolusi Sunnah}

a. Perkembangan Makna Sunnah.

Sunnah pada mulanya digunakan orang Arab untuk menunjuk pada tradisitradisi Arab dan kebiasaan nenek moyang mereka. Setelah Islam datang, sunnah digunakan untuk menyebut segala sesuatu yang bersumber dari perilaku-perilaku Nabi dan sahabat, juga idealitas sunnah orang Arab pra Islam berakhir (al Qadir, 1942: 122-123). Pengertian sunnah kemudian mengalami penyempitan pada abad kedua Hijriyah. Oleh Imam Syafi'i, sunnah hanya diartikan dan dibatasi pada sunnah Rasul (al Sarakhshy, 1372: 113-114).

Perubahan dan pergeseran makna sunnah pasca kemunculan Islam, menurut Goldziher disebabkan umat islam sangat menghormati dan mentaati model perilaku Nabi, sebagaimana orang Arab (penyembah berhala) mentaati tradisi nenek moyang mereka. Dengan demikian, konsep islam tentang sunnah merupakan revisi pernyataan-pernyataan dari pandangan-pandangan masyarakat Arab kuno (Goldziher, 1971: 25-26). Gagasan Goldziher tersebut ditentang oleh Azami. Menurut Azami, umat muslim mentaati dan meneladani perilaku Nabi, dikarenakan mengikuti perintah Allah dan juga rasulnya, dan bukan seperti halnya orang Arab yang menyembah berhala mentaati tradisi nenek moyangnya. Maka dari itu ada pemisah antara sunnah masyarakat jahiliyyah dengan sunnah masyarakat Islam, yaitu perintah Allah dan perintah Rasulnya (Azami, 1994: 21\&25).

b. Perkembangan Makna Hadits

Pada awalnya (sebelum Islam), hadits mempunyai makna cerita-cerita dan berita-berita secara umum, kemudian mengalami pergeseran, hadits digunakan untuk menunjukkan kabar-kabar yang berkembang dalam masyarakat 
keagamaan tanpa memindahkan maknanya dari konteks yang umum. Pada akhirnya hadits secara eksklusif digunakan untuk menunjukkan cerita-cerita tentang Nabi Muhammad saw (Ismail, 1994: 7-8).

Menurut Goldziher, ketika Islam datang, hadits mengalami perubahan dan penyempitan arti dari konteks umumnya menjadi khusus digunakan untuk cerita-cerita atau perkataan yang bersumber dari Nabi (Goldziher, 1971: 18). Terjadinya pergeseran makna hadits ini menurut Azami disebabkan pada masa permulaan kemunculan Islam, cerita-cerita dan perkataan Nabi mendominasi atas segala perkataan dan cerita-cerita yang lain di kalangan masyarakat pada waktu itu. Semakin lama, kata hadits menjadi semakin eksklusif dan sering digunakan di kalangan bangsa Arab untuk memaksudkan halhal yang bersumber dari Nabi. Sampai pada akhirnya, seiring dengan berjalannya waktu, perkataan hadits menjadi khusus digunakan untuk segala informasi dan komunikasi yang datang dari Nabi (Azami, 1977: 21-25).

c. Evolusi Sunnah ke Hadits/Hadits ke Sunnah

Paparan penjelasan diatas menyebutkan bahwa telah terjadi perbedaan antara makna hadits dan sunnah. Meskipun ada sebagian ulama yang menegaskan tidak adanya perbedaan antara keduanya. Namun, beberapa argumentasi secara meyakinkan menyatakan adanya perbedaan yang signifikan antara hadits dan sunnah. Sebagaimana yang telah dikemukakan oleh Fazlurrahman, dalam perkembangan Islam yang cukup panjang, hadits merupakan verbalisasi dari konsep sunnah. Sunnah merupakan sebuah bentuk perilaku yang bersifat situasional. Karena dalam prakteknya tidak ada dua buah kasus yang benarbenar sama latar belakang situasionalnya, secara moral, psikologis dan material. Maka dari itu sunnah harus dapat dikembangkan, diinterpretasikan, dan diadaptasikan. Dalam hal ini sunnah dengan sendirinya secara terus menerus mengalami evolusi dari generasi ke geneasi. Dengan begitu sunnah harus dipandang sebagai sebuah teladan, bukan kandungan khusus yang bersifat mutlak (Rahman, 1987: 85-86).

Fazlurrahman mengemukakan sebuah teori perkembangan hadits. Dalam perkembangannya, hadits mengalami tiga fase, yaitu: informal, semiformal dan formal. Sunnah pada fase informal terjadi pada masa Nabi masih hidup, pembicaraan perihal Nabi hanyalah bagian dari peristiwa yang terjadi dalam kehidupan sehari-hari para sahabat. Proses periwayatan (transmisi verbal) tentang Nabi bukanlah suatu kesengajaan untuk sebuah orientasi praktis. Karena salah satu peranan hadits yang memberikan bimbingan dalam praktek aktual masyarakat waktu itu sudah terpenuhi oleh Nabi (Rahman, 1987: 85-86). 
Fase semiformal terjadi setalah Nabi wafat, tepatnya pada masa sahabat dan tabi' in senior. Pada fase ini, penyebaran hadits Nabi mempunyai tujuan praktis, yakni sesuatu yang dapat dikembangkan menjadi praktek masyarakat muslim, peyebaran hadits menjadi sebuah kesengajaan. Pada masa ini, penafsiran bebas terhadap hadits Nabi oleh para penguasa dan hakim sesuai dengan situasi dan kondisi yang mereka hadapi pun menjadi sebuah keniscayaan, sehingga muncullah apa yang disebut dengan 'living sunnah'. Dampak dari perkembangan hadits secara semiformal adalah munculnya perbedaan praktek yang aktual (living sunnah) di berbagai daerah dalam imperium islam, bahkan terkadang saling bertentangan.

Fase semiformal dalam perkembangan hadits, menyebabkan munculnya fase ketiga, yaitu fase formal. Fase ini menuntut adanya keseragaman dan standarisasi di seluruh Dunia Islam. Fase ini menyebabkan sunnah yang hidup yang bersifat dinamis dengan proses interpreasi yang terus menerus terhadapnya menjadi corpus tertutup, baku-kaku dan stagnan serta dianggap sebagai keputusan dan ketentuan yang bersifat final demi sebuah alasan untuk keseragaman dan penyatuan ummat. Gerakan ini, dipelopori oleh al Syafi'i mempunyai tujuan menjaga stabilitas hukum dan menumbangkan haditshadits palsu yang pada waktu itu merajalela. Namun sayang, pada fase ini, sunnah yang semula bersifat dinamis berubah menjadi baku-kaku (Rahman, 1987: 32-33).

Baik sunnah maupun hadits harus difahami lebih progresif dan dinamis. Menuangkan kembali atau mencairkan kembali hadits-hadits yang telah ada ke dalam bentuk sunnah yang hidup (living sunnah) sebagaimana yang dilakukan oleh generasi awal melalui kerangka studi historis dan sosiologis merupakan sebuah kebutuhan umat saat ini. Hal ini penting dilakukan mengingat aneka ragam unsur dalam hadits dan reinterpretasi terhadapnya harus selalu dan selaras dengan perubahan-perubahan kondisi sosia moral saat ini. Penafsiran situasional dan historis dalam bentuk sunnah yang hidup akan membuat kaum muslim dapat menyimpulkan norma-norma dari hadits untuk kepentingan kebutuhan zamannya (Amal, 1989: 173).

Teori evolusi sunnah menjadi hadits yang diusung oleh Fazlurrahman mendapat dukungan dari Ignaz Goldziher yang menegaskan bahwa sunnah pada mulanya berhubungan dengan adat istiadat nenek moyang orang-orang Arab. Namun, dengan datangnya Islam, kandungan konsep sunnah mengalami perubahan, bukan lagi adat istiadat nenek moyang leluhur mereka, melainkan berubah menjadi model perilaku Nabi. Model perilaku tersebut kemudian 
diwartakan menjadi hadits (Goldziher, 1971: 25). Gagasan ini kemudian dikembangkan oleh orientalis-orientalis sesudahnya, semisal Yoseph Schacht yang menyatakan bahwa sunnah Nabi pada dasarnya merupakan kesinambungan adat istiadat pra Islam ditambah dengan aktivitas pemikiran bebas para pakar hukum islam masa awal. sedangkan hadits hanyalah produk kreasi kaum muslimin belakangan, karena kodifikasi hadits baru terjadi beberapa abad setelah Nabi wafat (Schacht, 1959: 98).

Gagasan mereka ini berseberangan dengan Jaladuddin Rahmat, ia mengatakan bahwa yang beredar pertama kali di kalangan kaum muslimin adalah hadits, bukan sunnah sebagaimana yang telah diungkapkan oleh Fazlurrahman dan Ignaz. Asumsi ini didasari oleh data historis bahwa ada sahabat yang menghafal dan menulis ucapan Nabi, hadits sudah ada sejak masa Nabi hidup (Rahmat, 1995: 230).

Kedua model pemikiran diatas, sebenarnya bisa di kompromikan. Karena pada kenyataannya tradisi hadits dan sunnah terjadi secara bersamaan. Hadits yang disebut Fazlurrahman sebagai tradisi verbal sudah ada sejak masa Nabi. Dalam sebuah riwayat yang disampaikan oleh Abu Hurairah, Nabi pernah memerintahkan salah satu sahabat untuk menuliskan khutbah yang baru saja disampaikannya, atas permohonan dari Abu Syah (al Bukhary, tt: II, 857). Demikian juga sunnah, tetap dilestarikan dan dijaga oleh generasi-generasi sesudah Nabi wafat. Kebutuhan terhadap formulasi sunnah Nabi, termasuk 'sunnah yang hidup' ke dalam bentuk hadits menjadi suatu kebutuhan yang sangat mendesak dan mendasar. Karena dalam jangka panjang struktur ideology-religious masyarakat muslim akan terancam kekacaun tak berujung jika tidak ada pangkal rujukan yang otoritatif. Kanonisasi sunnah ke dalam bentuk hadits muncul dalam skala besar-besaran ditujukan untuk menghadapi ekstrimisme dan penafsiran sewenang-wenang yang sudah gawat terhadap sunnah Nabi. Ini menandai berakhirnya proses penafsiran terhadap sunnah Nabi, termasuk 'sunnah yang hidup' karena sunnah Nabi sudah berubah bentuk menjadi verbal. Pada tahap ini muncullah gerakan baru yang dipelopori oleh Imam Syafi'i yang menyebarkan dogma bahwa sunnah yang harus dipegang adalah sunnah yang berasal dari Nabi. Yakni sunnah yang memiliki keabsahan sebagai sumber hukum islam adalah sunnah yang dapat dibuktikan berasal dari Nabi melalui mekanisme transmisi verbal (hadits). secara eksplisit imam Syafi'i mengatakan: "muthlaq al sunnah ma yatanawalu sunnata Rasulillah faqath" (Musahadi, 2000: 112), konsekwensinya adalah sunnah dalam bentuknya sebagai laporan dan cerita tentang generasi terdahulu 
harus dilakukan dengan penyaringan, mana yang berasal dari Nabi dan mana yang hanya diklaim berasal dari Nabi (Majid, 1986: xv).

\section{Simpulan}

Hadits yang disebut Fazlurrahman sebagai tradisi verbal sudah ada sejak masa Nabi. Demikian juga sunnah, tetap dilestarikan dan dijaga oleh generasi-generasi sesudah Nabi wafat. Kebutuhan terhadap formulasi sunnah Nabi, termasuk 'sunnah yang hidup' ke dalam bentuk hadits menjadi suatu kebutuhan yang sangat mendesak dan mendasar. Karena dalam jangka panjang struktur ideology-religious masyarakat muslim akan terancam kekacaun tak berujung jika tidak ada pangkal rujukan yang otoritatif, dan tidak ada yang mampu menjembatani perbedaan ulama tentang definisi hadits dan sunnah. Dengan mengacu pada pemahaman bahwa hadits merupakan sunnah yang diverbalkan, menurut penulis akan menjadikan hadits atau sunnah selalu relevan dengan konteks zaman, dengan begitu, pemahaman yang anti humanisme, bias dan ekstreme dapat dihindari.

\section{Daftar Pustaka}

Abbas, Hasyim. 2004. Kritik Matan Hadits Versi Muhaddisin dan Fuqaha Yogyakarta: Teras.

Abdullah, Amin. 2000. Kajian Ilmu Kalam di IAIN: Menyongsong Perguliran Paradigma Keilmuan Keislaman pada Era Milenium Ketiga”, dalam Jurnal Al Jami'ah: Journal of Islamic Studies IAIN SUKA. Nomor 65/VI

Abdullah, Amin. 2012. Islamic Studies di Perguruan Tinggi. Yogyakarta: Pustaka Pelajar.

Al Asfahani, Al Raghib. tt. Mu’jam Mufradat al Faz al Quran. Libanon: Dar al Fikr.

Al Sarakshy, Muhammad ibn Ahmad Abi Sahl. 1372 H. Ushul al Sarakshy. Heiderabad: Ihya' al Ma'arif al Nu'maniyyah.

Al Shahrawi, Ibrahim Dasuqi, 1971. Mushthalah al Hadits: Shirkat al Thaba'at al Fanniyyat al Muttahidah.

Al Siba'i, Musthafa. 1994. al Sunnah wa Makanatuha fi al Tashri' al Islami. Kairo: Dar al Qawmiyyat li al Thaba'ah wa al Nashr.

Al Siddiqie, M Hasbi. 1991. Sejarah dan Pengantar Ilmu Hadits. Jakarta: Bulan 
Bintang.

Amal, Taufik Adnan. 1989. Islam dan Tantangan Modernis: Studi Atas Pemikiran Fazlur Rahman. Bandung: Mizan.

Azami, Muhammad Mustafa. 1977. Studies in Hadits Methodology and Literature. Indianapolish: Islamis Teaching Center.

Azami, Muhammad Musthafa, 1994. Hadits Nabawi dan Sejarah Kodifikasinya, terj. Ali Mustafa Ya'kub, Jakarta: Pustaka Firdaus.

Baqi, Muhammad Fuad. 1992. 'Abdul al Mu'jam al Mufahras li al Faz al Quran. Libanon: Daar al Fikr.

Al Fairuzzabadi. 1983. Majdu al Din Muhammad Ibnu Ya'qub. Al Qamus al Muhith Bairut: Dar al Fikr.

Goldziher, Ignaz. 1971. Muslim Studies. London: George Allen \& Unwin.

HAM, Musahadi, 2000. Evolusi Konsep Sunnah: Implikasinya Pada Perkembangan Hukum Islam. Semarang: Aneka Ilmu.

Hasan, Ahmad, 1994. The Early Development of Islamic Jurisprudence. India: Adam Publisher \& distribution.

Ibnu al Mandhur, Jamal al Din. Tt. Lisan al Arab. Mesir: Dar al Misriyyah.

Ibrahim, Muhammad Ismail. Tt. Mu'jam al Alfaz wa al A'lam al Quraniyyah. Kairo: Dar al Fikr.

'Itr, Nur al Din. 1992. Manhaj al Naqd fi 'Ulum al Hadits. Damaskus: Dar al Fikr.

Ismail, Syuhudi. 1994 Pengantar Ilmu Hadits. Bandung: Agkasa.

Ismail, Syuhudi. 1988. Kaedah Kesahehan Sanad Hadits. Jakarta: Bulan Bintang.

Khatib, Muhammad 'Ajaj. 1989. Ushul al Hadits. Bairut: Dar al Fikr.

Mahmudunnaser. 1981. Islam It's Concept and Historiy. New Delhi: Nusrat 'Ali Nasri.

Majid, Nurcholis. 1986. Imam Syafi'I: Peletak Dasar Metodologi Pemahaman 
Hukum Islam, Kata Pengantar dalam Muhammad Ibnuu Idris al Syafi'i, al Risalah Imam Syafi'I, Terjemahan oleh: AhmdieThoha. Jakarta: Pustaka Firdaus.

Al Qadir, 'Ali Hasan 'Abd. 1942. Nazharat al 'Ammah fi Tarikh al Islamy. Kairo: Ulum Pres.

Rahman, Fazlur. 1965. Islamic Methodology in History. Karachi: Central Institute of Islamic Studies.

Rahman, Fazlur. 1987. Islam, Terjemahan oleh: Senoaji Saleh. Jakarta: Bumi Aksara.

Rahmat, Jalaluddin. 1995. Dari Sunnah Ke Hadits Atau Sebaliknya, dalam Kontekstualisasi Doktrin Islam Dalam Sejarah. Jakarta: Paramadina.

Al Razi, 'Abd al Rahman Ibnu Abi Hatim. Tt. Taqaddumat al Ma'rufah li Kitab al Jarh wa al Ta'dil. Hyderabat: Dairah al Ma'arif al 'Uthmaniyyah, t, tp.

Shalih, Subhi Shalih. 1989. 'Ulum al Haadith wa Musthalahuh. Bairut: Dar al 'Ilmi li al Malayin.

Sabbaq, Muhammad. 1972. Al Hadits al Nabawy. Al Maktab al Islamy.

Schacht, Yoseph. 1959. The Origin of Muhammaden Jurisprudence. London: Oxford. 